Article

\title{
The Role of Ethical Marketing Issues in Consumer-Brand Relationship
}

\author{
Jung-Yong Lee ${ }^{1}$ and Chang-Hyun Jin ${ }^{2, * \mathbb{C}}$ \\ 1 Department of Business Administration, SungKyunKwan University, Seoul 03063, Korea; \\ jaylee8206@gmail.com \\ 2 Department of Business Administration, Kyonggi University, Gyeonggi-do 16227, Korea \\ * Correspondence: chjin@kgu.ac.kr or cuigeoqi@mail.com; Tel.: +82-31-249-9427
}

Received: 13 October 2019; Accepted: 13 November 2019; Published: 20 November 2019

\begin{abstract}
This study investigated the components of ethical marketing such as product, price, place, and promotion using ethical views on the consumer-brand relationship and perceived product quality in B2C (business to consumer) transactions. It examined whether the quality and consumer-perceived product quality of a consumer-brand relationship affects corporate brand loyalty. Data from a panel of 1,200 consumers who had multiple experiences with a company's products and brands were used to test the hypotheses, which were verified using structural equation modeling. The results support the proposed research model with statistical significance. A corporate marketing mix strategy with respect to ethical issues was crucial to generate a consumer-brand relationship and perceived product quality, which were influenced by corporate brand loyalty. However, the outcomes associated with each area of ethical marketing practice-through the relationship between the mediating variables and the dependent variable - vary with the business type and other characteristics. Without considering this aspect, it is difficult to generalize the current results. Thus, further analyses are required in future studies. However, this study identifies influential factors for building a relationship that involves ethical marketing practice, relationship quality, and brand loyalty in B2C transactions. Finally, this study suggests implications for companies regarding which aspects of (un)ethical marketing practices should be reinforced to achieve corporate brand loyalty. This study confirmed the significant correlation between the marketing mix strategy from ethical issues, which form the basis of transactions and relationship quality.
\end{abstract}

Keywords: ethical marketing; consumer-brand relationship; perceived product quality; brand loyalty

\section{Introduction}

Corporate marketing programs primarily focus on attaining consumer loyalty. Such loyalty is often reflected through favorable attitudes toward the company in the consumer-brand relationship and in product evaluations. The main purpose is to enhance competitive advantages in the marketplace. In today's rapidly changing marketing environment, building strong relationships and brand loyalty with the consumer is becoming increasingly important for companies. Some studies have argued that corporations should deliver their brand message and sell their products to consumers while considering social and environmental issues. Strategies that focus on shared issues increase consumers' interest in purchasing products or services from such companies [1].

Maintaining a relationship with the consumer and building brand loyalty are major challenges in the current marketing environment [2]. Today's highly competitive marketplace makes these challenges even more daunting. For instance, modern society demands companies to behave responsibly and ethically toward their stakeholders [3,4]. 
Research on ethical marketing strategies, which are formulated to gain competitive advantage, has been conducted for almost all business areas [5,6]. Ethical marketing practices by a company affect the daily routine of consumer consumption activity [7]. All ethical marketing practices by a company are closely related to purchasing products or services, regardless of whether the company is aware of the strengths and weaknesses of the consumer purchasing power [8]. Corporate managers and marketers have realized the importance of ethical practice in the advancement of business sustainability $[7,9,10]$, promotion of ethical management [6], and general marketing issues (e.g., product safety, pricing, and advertising) [11]. An ethical, or unethical, corporation's business conduct is inherently likened to its overall reputation and evaluation; it also emphasizes the corporation's essential factors to remain competitive in the marketplace $[7,9,10,12]$.

Despite the apparent importance of ethical marketing practice with respect to relationship building, product evaluation, and strong brand loyalty, only a few studies have examined the marketing mix strategy-such as, product, price, place, and promotion-from an ethical issues standpoint as having a critical influence on consumer attitude formation (e.g., product evaluation and brand loyalty). That is, how the "marketing mix strategy from ethical issues" functions reflects the consumer product evaluation, brand perception, and brand loyalty.

The hypothesis, or scope, of this article is to examine the components of the marketing mix from an ethical perspective and their effect on the consumer-brand relationship and perceived product quality in B2C transactions. We also examine whether the consumer-brand relationship quality and consumer-perceived product quality affect corporate brand loyalty. The theoretical and practical implications of the findings and the study's limitations and directions for future research are discussed toward the end of the paper.

\section{Theoretical Background}

\subsection{Ethics and Ethical Marketing}

In the literature, the term "ethics" refers to a set of moral norms, principles or values, and the nature and grounds of morality that guide people's behavior such as moral judgments, standards, and rules of conduct $[13,14]$. The terms "unethical" or "ethical" describe an individual's subjective moral judgment of right/wrong or good/bad. By nature, moral sentiments can be either neutral or negatively/positively valanced [7]. Shea argued that "ethics is a discipline that deals with what true and false is [15]. Ethics in marketing transpires from marketing executives' relationships with organizational members, consumers, rivals, and the sides and include public opinion in the exchange process" [16]. On the other hand, business ethics is a vital topic for scholars and practitioners [17,18]. Corporate ethics requires setting and maintaining minimum standards of responsibility and behavior that companies should follow or a system of accountability for a company's implementation of its ethical role [19].

Considering previous business ethics research, a plethora of research has focused on the relationship between ethical management and ethical activities. Ethics is also closely related to social responsibility because social responsibility relating to ethics includes social relationships within society, in which enterprises work [20-23]. Consumers in current society continue to demand more high-quality products, and they display a preference for brands that are socially reputable even at higher prices when evaluating similar products [24]. Ethical marketing practices provide managers and marketers with a guideline concerning what they should do when they face an ethical problem [25]. Gaski defined "ethical marketing as a code of morals and conduct used in marketing practices" [26]. Some scholars define it as "the systematic study of how moral standards are applied to marketing decisions" [27]. Marketing continuously involves ethical and moral activities [11,28]. Ethical marketing practices include product-related ethics, price-related ethics, place-related ethics, and promotion-related ethics.

Product-related ethics includes product safety, product liability, and product imitation, which are subject to legal regulations. The marketing mix strategy from ethical issues have been emphasized by 
several researchers [1,21,28-33]. Mogan argued that ethics and legal subjects are discussed more in the new product development process to obtain a competitive advantage as well as determine how these products damage consumers [34]. Price-related ethics includes the proportion principle and fairness principle. Price-related ethics should be equal or proportional to benefit, which is taken by the consumers [35,36] (p.22). The proportion principle says that price levels should be proportional to the size or significance of the benefit gained from a product or service. Unreasonable pricing might affect the structure of competition $[37,38]$. Place-related ethics arises largely in dynamic relationships along distribution channels. Organizations, which play a dominant role in the distribution process for products and services from producers to wholesalers to retailers and finally to consumers, occasionally commit unethical behavior, such as abusing their power [36,39]. Promotion-related ethics issues could be analyzed with advertising and personal selling [36]. Promotion-related ethics includes moral problems related to advertising, sales promotion, and public relations. Such a moral problem can involve an advertisement itself or a sponsor or agency. Salespeople can also encounter moral problems in the process of contacting customers. Other examples include problems related to sales promotions to consumers, brokers, and retailers, and problems that occur in relationships with media organizations for advertising purposes $[37,40,41]$. For perspective from this discussion, the study should be studied to build a theoretical model that explains the relationship between the marketing mix from ethical issues and relationship quality and outcomes of consumer behavior.

\subsection{Consumer-Brand Relationship Quality, Perceived Product Quality, and Brand Loyalty}

Consumer-brand relationship quality is a comprehensive concept that reflects the intensity, depth, continuity, and effect of the relationship between a consumer and brand. Consumer-brand relationship quality could be identified to include brand effect [42], brand identification [43], intimate relationships [44], brand trust [45], interdependence [43], satisfaction [46], and brand commitment [47].

Previous models of such a relationship posit a hierarchy of common components such as a cognitive, an affective, and a conative component. These processes are involved in establishing and maintaining the relationship between consumers and brands [48]. Key factors that affect consumer-brand relationship quality include purchasing experience, emotional experience, act experience, cognitive beliefs, and brand commitment $[43,46,49,50]$. A consumer's unilateral affective relationship with a brand is more like a fan's love for a sports star or a singer than the love that occurs in a personal relationship [51]. To improve the consumer-brand relationship and reinforce a company's moral aspect and ethical relationships with customers, it is necessary to consider factors that are unique to consumer-brand relationship quality. Consumer-brand relationship quality is an association that is built through a process in which consumers and brands, as two equal parties, contribute to and interact with each other in a marketplace [43].

\subsection{Perceived Product Quality}

Perceived product quality has been variously defined in academic fields. Perceived product quality has been defined as the consumer's judgment about a product's overall excellence or superiority [52], a special type of association [53], and the customer's perception of the overall quality or superiority of the product. Perceived quality is different from actual or objective quality, product-based quality, and manufacturing quality [53]. A perspective from argumentation is that perceived product quality is the consumer's perception of the overall components of a product, such as performance, features, reliability, conformance, dedicated design, durability, serviceability, and aesthetics.

\subsection{Brand Loyalty}

The terms of loyalty is applied in diverse situations; therefore, the definition of loyalty differs depending on the situation. Recent studies of loyalty have used "a behavioral index, an attitudinal index, or a combined index incorporating behavioral, attitudinal, and cognitive aspects according to the nature of the research" [54-56]. From a behavioral perspective, loyalty can be determined only by purchase behavior 
with a focus on the outcome of such behavior. Brand loyalty is defined as "the likelihood of a customer repurchasing a certain product or service or recommending it to others; it is argued that customer loyalty results in continuous purchase behavior" [54-58]. For some scholars, brand loyalty refers to "a deeply held dispositional commitment that induces users to resist situational influences and marketing efforts that might have the potential to cause brand-switching behavior" [55,59]. Brand loyalty is classified as affective loyalty and action loyalty. The best means of measuring brand loyalty is to measure affective loyalty [60-62]. Affective loyalty refers to "the consumer's preference and affinity for a specific brand; however, the actual purchase behavior has not yet occurred. Action loyalty is shown by the actual purchase behavior conducted by consumers for a specific brand" [62]. Oliver emphasized that brand loyalty is considered a critical element in maximizing and delivering long-term corporate profitability [53,60]. Brand loyalty is considered one of the critical corporate tools to achieve survival and growth. Gaining loyal customers has become a major marketing goal and an essential basis to develop a competitive edge [63].

\section{Hypotheses and Theoretical Model}

The marketing mix strategy with ethical views pertain to moral beliefs and behavior that inform corporate activity, in which ethical consideration is applied to marketing decisions [64]. The ethical marketing practice problems occur more frequently in gray areas (e.g., underground economy) in which legal acts can occasionally be unethical or in which the legitimacy or ethicality of behavior is uncertain. In such situations, the role of marketing ethics has become increasingly important. Forming relationships between brands and consumers affects dynamic interaction between consumers and products, creating a positive effect on the brand experience [65]. A higher level of ethical responsibility leads to an increase in trust between the company and stakeholders [66].

Brands and consumers mutually affect each other by their interaction. The relationship between a consumer and brand reflects the cognitive, emotional, and behavioral processes that inform a relationship between two people [67]. Here, we find a contact point between the ethical marketing practice and consumer-brand relationship quality because consumers evaluate a brand and build a relationship quality through a series of processes, which include perception of and experience with a brand and interaction with the brand. Ethical marketing practice is one of the most visible fields in a company's diverse activities that is observable by consumers. Additionally, ethical marketing practice is an important factor that influences consumer perceptions and evaluation of a brand.

As noted above, in the past, moral problems in marketing have largely involved product safety, price fixing, bribery, deceptive advertising, and anti-social or unethical information collection. Lately, such moral problems have arisen in new aspects as companies adjust to environmental change $[7,9,10,12,68]$. Ethical problems involving fairness, probity, and product, and human resource management are affecting subjective evaluations of product quality more now than in the past.

Deceptive prices mislead the consumer from the basic feature of purchase. Setting the right price in the marketplace is one of the best means to improve the relationship between a company and consumer [1,31]. Truthful information about the product is needed to protect the consumer, and the negative effect of advertisements causes consumers to reach irrational decisions [29,30,69]. Product advertising should be easily understandable to common consumers. This point is in the code of ethics for better business bureau organizations $[37,40,41,70]$. The above discussion implies that ethical marketing practice in the firm's marketing mix can cause consumers to make irrational decisions, which might ultimately generate harmful consequences for the company. Assuming there is a direct relationship between a corporation's ethical marketing practice and its consumer-brand relationship quality, we propose the following hypotheses:

Hypothesis 1-1 (H1-1). The product-related ethics will have a positive effect on consumer-brand relationship quality. 
Hypothesis 1-2 (H1-2). The price-related ethics will have a positive effect on consumer-brand relationship quality.

Hypothesis 1-3 (H1-3). The place-related ethics will have a positive effect on consumer-brand relationship quality.

Hypothesis 1-4 (H1-4). The promotion-related ethics will have a positive effect on consumer-brand relationship quality.

Perceived product quality must satisfy consumer needs and wants, such as product safety and health standards [71] and the environment [72]. Within high-quality products, consumers can select a brand that is deemed to deliver ethical values and behave responsibly [73]. Based on these studies of the concept of product quality, we define product quality as the subjective quality that a consumer perceives in a product. A firm that establishes a reputation for marketing its products or services in a morally responsible manner receives respect and trust from customers, suppliers, employees, and stakeholders because the company strikes the right balance between the rights of interested parties and its own interests when making decisions or implementing plans [74]. Companies can achieve continuous benefit only when their transactions are based on reciprocal relationships between the interested parties. Assuming there is a direct relationship between a corporation's ethical marketing practice such as marketing mix strategy and its perceived-product quality, we propose the following hypotheses:

Hypothesis 2-1 (H2-1). The product-related ethics will have an influence on perceived product quality.

Hypothesis 2-2 (H2-2). The price-related ethics will have an influence on perceived product quality.

Hypothesis 2-3 (H2-3). The place-related ethics will have an influence on perceived product quality.

Hypothesis 2-4 (H2-4). The promotion-related ethics will have an influence on perceived product quality.

Marketing is one of the most visible fields of a company's diverse activities that is observable by consumers. Therefore, the ethical propriety of a firm's marketing practices is an important factor that affects the perception and evaluation of a brand [67]. Blackstone argues that consumer-brand relationship quality is a critical element in enabling consumers to trust a company and find its products satisfactory. Consumers evaluate a brand by applying emotional and relational criteria to activities, community, expectations, and stories when they choose a brand, and a consumer-brand relationship is built during this process. Consumers assess the value of a brand by reference to their own experience rather than focusing on the intrinsic attributes of a product [75].

According to Keller, "consumer-brand resonance is the final stage in the establishment of a brand asset, a phenomenon related to the brand-consumer relationship" [76]. Moreover, "consumers engage in brand loyalty behavior, active participation, brand immersion, and community spirit at this stage of the branding process" $[55,56,77-79]$. Previous work verifies that the consumer-brand relationship improves brand loyalty $[55,56,80]$. Aggarwal argues that the consumer-brand relationship necessarily accompanies financial exchange, which differentiates it from interpersonal relationships, finding that consumers tend to form unilateral affective relationships with a brand [51]. Establishing a strong consumer-brand relationship is the ultimate goal of branding because a consumer-brand relationship can also promote consumer loyalty to a brand $[77,78,80]$.

Previous studies have found that perceived product quality has a positive effect on customer satisfaction, commitment, and brand loyalty [81-83]. Perceived quality should lead consumers to trust and identify with a brand. Moreover, perceived quality is closely related to customer satisfaction because people with higher quality perceptions of a brand also exhibit higher customer satisfaction $[84,85]$. 
Perceived quality is attributed to such a company through beliefs [86]. Pyun et al. found that people who exhibit or report high perceived brand quality are more likely to recognize a perceived brand [87].

Perceived quality can be viewed as the difference between overall quality and undetected quality. Furthermore, perceived quality can lead to consumer satisfaction, which is determined by perceived performance and expectation [88]. The quality of a product includes its capability to perform to the customers' needs and expectations [89]. Brand loyalty is expected to result from consumers' overall disposition toward the brand, and brand loyalty is treated as the final outcome of a consumer's brand evaluation [90]. Brand loyalty is viewed in terms of behavior and attitude in the marketing literature. For this reason, the consumer-brand relationship and product quality might be expected to play an important, influential role and affect brand loyalty.

Hence, this study proposes the following hypothesis based on the concept that the level of the consumer-brand relationship and product quality will have a significant effect on the formation of brand loyalty. We assume that a company's marketing ethics are related to the consumer-brand relationship and that the consumer-brand relationship, in turn, affects brand loyalty. These observations lead to the following hypotheses:

Hypothesis 3 (H3). Consumer-brand relationship quality will have a positive effect on brand loyalty.

Hypothesis 4 (H4). Perceived product quality will have a positive effect on brand loyalty.

How consumers perceive a company is becoming increasingly diversified. Some scholar mentioned that "companies are pursuing sustainable corporate growth to improve relationships with consumers or to maintain amicable relationships with them" [55]. As companies continue to develop ethical marketing practices such as a marketing mix, it will be very meaningful to study consumer perceptions of the activities, consumer-brand relationship, perceived product quality, and brand loyalty. In this study, we chose the consumer-brand relationship and perceived product quality as mediating variables. We examined the mediating effects of these two variables and assumed that a company's ethical marketing practice are related to the consumer-brand relationship and perceived product quality and that the consumer-brand relationship and perceived product quality affect brand loyalty. Based on the literature review and previous discussion, we propose the following hypotheses:

Hypothesis 5 (H5). The ethical marketing practices (product-related ethics: H5-1; pricing-related ethics: H5-2; place-related ethics: H5-3; and promotion-related ethics: H5-4) will affect brand loyalty through the mediating effects of consumer-brand relationship quality.

Hypothesis 6 (H6). The ethical marketing practices (product-related ethics: H6-1; pricing-related ethics: H6-2; place-related ethics: H6-3; and promotion-related ethics: H6-4) will affect brand loyalty through the mediating effects of perceived product quality.

We propose the above research hypotheses to inform our investigation of the role of ethical marketing practices on the consumer-brand relationship and perceived product quality in B2C transactions. Based on the research hypotheses and theoretical considerations, we developed our research model (see Figure 1). 


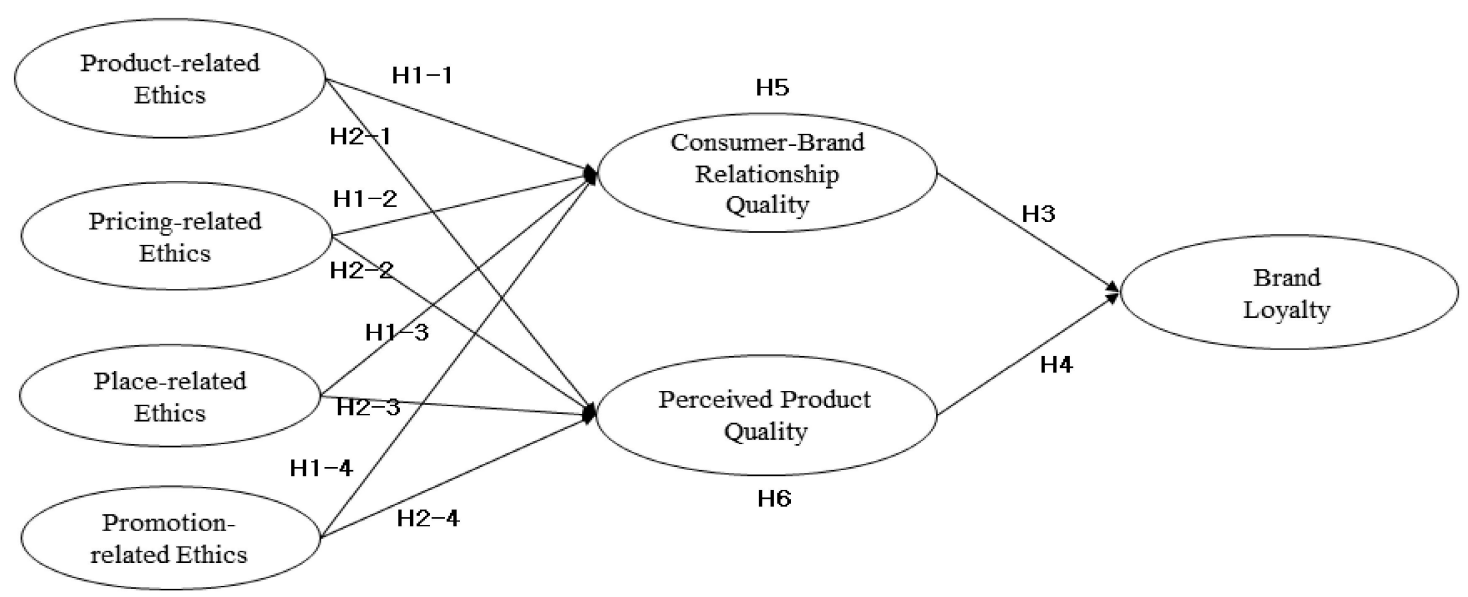

Figure 1. Suggested conceptual model.

\section{Research Methodology}

\subsection{Questionnaire Development and Data Collection}

Before distributing the survey questionnaire, we checked whether there were any conceptual errors in the survey questions by consulting researchers and professors in business administration. After the pretest, the questionnaire form was developed. The questionnaire used in this study and based on the literature review are related to independent and dependent variables.

Participants (1200 consumer panel members who registered with a research company) were then contacted by phone and were asked to participate in this study. Investigator asked participants to visit to the online survey website. The survey method suggested by previous study was applied to this study $[55,56]$. Investigator gave them $\$ 5.00$ gift cards to increase the response rate. This study conducted a survey of a panel of the company's consumers who had knowledge of the company's ethical marketing issues and had experience with the company, products, and brand (e.g., Hanwha group is a lager corporation in Korea) more than once. This survey was reasonable for participants because this company and product are familiar to them and it was not difficult to evaluate the company, product, and brand when they answered the questions.

The instruments consisted of two parts, with demographic questions placed at the beginning. The second part of the survey included questions on ethical marketing practices (e.g., product-, pricing-, place-, and promotion-related ethics), the consumer-brand relationship, and perceived product quality and brand loyalty. Table 1 provides the demographic characteristics of the sample participants.

Table 1. Demographic profile.

\begin{tabular}{llcc}
\hline & Index $(\mathbf{n}=\mathbf{1 2 0 0})$ & Frequency & \% \\
\hline \multirow{2}{*}{ Gender } & Male & 634 & 53 \\
& Female & 566 & 47 \\
\hline \multirow{3}{*}{ Age Category } & 20 to 29 years & 236 & 20 \\
& 30 to 39 years & 331 & 28 \\
& 40 to 49 years & 336 & 28 \\
& 50 years and older & 297 & 25 \\
\hline \multirow{3}{*}{ Education Level } & High School & 260 & 22 \\
& College degree level & 526 & 44 \\
& Graduate degree level & 414 & 35 \\
\hline \multirow{3}{*}{ Monthly household Income } & Up to \$2000 & 417 & 35 \\
& \$2001-\$3000 & 332 & 28 \\
& \$3000-\$5000 & 198 & 17 \\
\hline
\end{tabular}




\subsection{Instrument Construction}

The operational definition of ethical marketing practices used in this study is based on the literature on ethical marketing and business. Ethical marketing practices refer to "moral judgment and behavior standards in marketing practice in a marketing area" $[1,9,91]$. We categorize the marketing mix strategy from ethical issues as product-related, price-related, place-related, and promotion-related ethics $[1,31,33,64,69,72]$.

Product-related ethical issues constitute the level of product safety, quality, eco-friendliness, packaging and branding, and warranty (e.g., Is the product safety information clearly indicated on the packaging?).

Price-related ethical issues constitute using predatory pricing strategies, illegal pricing, and fraudulent or false pricing (e.g., Does the manufacturer refrain from using a predatory pricing strategy of intentionally lowering prices to eradicate competitors?).

Place-related ethical issues constitute the degree of the sales policy, level of partnership, and degree of transparent transaction (e.g., Does the manufacturer refrain from controlling transactions by abusing its status?).

Promotion-related ethical issues constitute advertising under legal legislation and degree of misleading or deceptive aspects (e.g., Does the manufacturer refrain from providing fraudulent, false, and exaggerated advertisements to consumers).

The study survey is based on the above definitions, with questionnaire items drawn from extant studies on ethical marketing practices. Twenty-eight items measure the marketing mix strategy from ethical issue, namely, seven sub-questions for product-related ethics, seven sub-questions for pricing-related ethics, eight sub-questions for place-related ethics, and six sub-questions for promotion-related ethics.

The operational definition of the consumer-brand relationship quality is based on the general definition of a brand. A brand, which is often visible as a mark of possession on a product, represents the differentiation in value of a product relative to a competitor's products and connects companies to consumers. In this respect, a consumer-brand relationship quality refers to "the belief that using a certain brand provides value and benefit" $[43,46,78,88]$. We revise and complement the scale for the consumer-brand relationship used in extant studies to fit the current study and, thus, measure the consumer-brand relationship using 15 questions (e.g., I really like to talk about the company's brand that I like with others).

Perceived product quality is defined as follows: "An overall product evaluation was based on consumer perceptions of the product's quality and of its overall excellence or superiority such as being of high quality, being a dedicated design product, and having fine workmanship" [52,71]. For example, "This company's product has a dedicated design." After recomposing the questions used in extant studies, we measure perceived product quality using three questionnaire items [52].

Brand loyalty is defined as "consumers' attachment to, trust in, and feeling toward a certain brand [88] and the frequency of preference for a certain brand leading to repeated purchases" [56]. It is measured by four items after correcting and modifying the questionnaire items from extant studies to fit the current study $[56,88,90]$ : For example, “I am willing to repurchase this company's product in the near future." Participants were asked to rate their level of agreement on the structured questions on a five-point Likert scale that ranged from one (strongly disagree) to five (strongly agree). All questionnaire items are measured using a five-point Likert scale (see Appendix A).

\section{Data Analysis}

\subsection{Assessment of the Measurement Model}

The statistical package SPSS 15.0 and EQS6b used to test hypothesis in this study. The study also verified the goodness of fit and the measurement model with confirmatory factor analysis. Next, structural equation modeling (SEM) was used to examine relationships between the constructs [92-94]. 
To verify confirmatory factor analysis (CFA), this study ascertained that the model's goodness of fit satisfied the advised base values $[92,93,95,96]$.

The reliability and validity of the variables were tested [96-98]. Convergent validity was assessed using Cronbach's alpha. Discriminant validity was assessed by comparing the correlation of components to the average variance extracted (AVE). The Cronbach's alpha mean for all concepts is greater than 0.7, indicating that this study has sufficient reliability. This study's AVE also satisfies the standard of 0.5 , indicating that the measurement indexes satisfy the requirement for convergent validity [97].

To verify discriminant validity, the AVE of each of the two potential factors was compared with the square of the correlation between the two potential factors, as reported in Tables 2 and 3. The extracted AVE is between .689 and .834 , and the means of the squares of the correlation coefficients are between 0.031 and 0.136 . This mean that the means of the squares of the correlation coefficients is greater than an AVE. Therefore, the seven constructs of the research theory have sufficient validity.

Table 2. Internal consistency of the constructs.

\begin{tabular}{|c|c|c|c|c|}
\hline & Items & Cronbach's alpha & C. $\mathbf{R}$. & AVE \\
\hline Product-related Ethics & 5 & 0.867 & 0.923 & 0.703 \\
\hline Price-related Ethics & 7 & 0.923 & 0.950 & 0.721 \\
\hline Place-related Ethics & 6 & 0.954 & 0.958 & 0.732 \\
\hline Promotion-related Ethics & 6 & 0.932 & 0.883 & 0.689 \\
\hline CBRQ & 15 & 0.942 & 0.864 & 0.802 \\
\hline PPQ & 3 & 0.893 & 0.869 & 0.834 \\
\hline BL & 4 & 0.896 & 0.933 & 0.757 \\
\hline
\end{tabular}

Note: C.R. = composite reliability; A.V.E. = average variance extracted; CBRQ: Consumer-brand relationship quality; PPQ: Perceived product quality; and BL: Brand loyalty.

Table 3. Discriminant validity.

\begin{tabular}{llllrrrrr}
\hline & AVE & $\mathbf{1}$ & $\mathbf{2}$ & $\mathbf{3}$ & $\mathbf{4}$ & $\mathbf{5}$ & $\mathbf{6}$ & $\mathbf{7}$ \\
\hline Product & $0.703^{*}$ & 1 & & & & & & \\
Price & $0.721^{*}$ & $0.136^{*}$ & 1 & & & & & \\
Place & $0.732^{*}$ & $0.091^{*}$ & $0.121^{*}$ & 1 & & & & \\
Promotion & $0.689^{*}$ & $0.101^{*}$ & $0.137^{*}$ & $0.131^{*}$ & 1 & & & \\
CBRQ & $0.802^{*}$ & $0.043^{*}$ & $0.038^{*}$ & $0.036^{*}$ & $0.041^{*}$ & 1 & & \\
PPQ & $0.834^{*}$ & $0.031^{*}$ & $0.032^{*}$ & $0.031^{*}$ & $0.042^{*}$ & $0.086^{*}$ & 1 & \\
BL & $0.757^{*}$ & $0.037^{*}$ & $0.027^{*}$ & $0.032^{*}$ & $0.031^{*}$ & $0.074^{*}$ & $0.068^{*}$ & 1
\end{tabular}

Note: * squared correlation coefficients, CBRQ: Consumer-brand relationship quality; PPQ: Perceived product quality; and BL: Brand loyalty.

Although the measurement tools used in this study and based on the literature review are related to marketing ethics [99], it is important to test them for reliability and validity. For this purpose, a multi-method approach to confirm the reliability and validity of the constructs was applied. This study assessed common method bias using exploratory factor analysis (EFA) with maximum likelihood (see Table 4), referred to as common method variance. The amount of spurious covariance was shared among variables because of the common method used in collecting data $[93,95,96]$. Thus, this study checked for possible common method variance using Harman's single-factor test $[100,101]$ for (in)dependent variables. According to this approach, common method variance is present if a single factor accounts for most of the covariance in the dependent and independent variables. This study found no dominant factor emerging from factor analysis, implying that common method variance was not a serious problem. After collecting and cleaning the data, verification tests were conducted to determine the measurement model's validity. This study initially performed principal component factor analysis with varimax rotation on the initial items, employing a factor weight of 0.50 as the minimum cutoff value. After initial factor analysis, two items for product ethics that were cross loading 
were deleted from further analysis. Two items for place ethics that did not satisfy the criterion $(0.05)$ were deleted from further analysis.

Table 4. Results of the factor analysis.

\begin{tabular}{|c|c|c|c|c|c|}
\hline \multicolumn{3}{|c|}{ Independent Variables } & \multicolumn{3}{|c|}{ Dependent Variables } \\
\hline Construct & Items & F.L & Construct & Items & F.L \\
\hline \multirow{5}{*}{ Product-related Ethics } & Prod3 & 0.758 & \multirow{15}{*}{$\begin{array}{l}\text { Consumer-brand Relationship } \\
\text { Quality }\end{array}$} & CBR1 & 0.731 \\
\hline & Prod4 & 0.778 & & CBR2 & 0.703 \\
\hline & Prod5 & 0.764 & & CBR3 & 0.726 \\
\hline & Prod6 & 0.791 & & CBR4 & 0.786 \\
\hline & Prod7 & 0.794 & & CBR5 & 0.816 \\
\hline \multirow{7}{*}{ Pricing-related Ethics } & Pric1 & 0.793 & & CBR6 & 0.745 \\
\hline & Pric2 & 0.802 & & CBR7 & 0.679 \\
\hline & Pric3 & 0.812 & & CBR8 & 0.783 \\
\hline & Pric4 & 0.789 & & CBR9 & 0.775 \\
\hline & Pric5 & 0.762 & & CBR10 & 0.813 \\
\hline & Pric6 & 0.734 & & CBR11 & 0.776 \\
\hline & Pric7 & 0.690 & & CBR12 & 0.778 \\
\hline \multirow{6}{*}{ Place-related Ethics } & Pala3 & 0.725 & & CBR13 & 0.748 \\
\hline & Pala4 & 0.702 & & CBR14 & 0.832 \\
\hline & Pala5 & 0.723 & & CBR15 & 0.884 \\
\hline & Pala6 & 0.693 & \multirow{3}{*}{ Perceived-Product Quality } & PPQ1 & 0.853 \\
\hline & Pala7 & 0.723 & & PPQ2 & 0.887 \\
\hline & Pala8 & 0.704 & & PPQ3 & 0.856 \\
\hline \multirow{6}{*}{ Promotion-related Ethics } & Prom1 & 0.791 & \multirow{6}{*}{ Brand Loyalty } & BL1 & 0.823 \\
\hline & Prom2 & 0.763 & & BL2 & 0.843 \\
\hline & Prom3 & 0.761 & & BL3 & 0.832 \\
\hline & Prom4 & 0.773 & & BL4 & 0.853 \\
\hline & Prom5 & 0.754 & & & \\
\hline & Prom6 & 0.702 & & & \\
\hline Eigenvalues & \multicolumn{2}{|c|}{$\%$ of Variance } & Eigenvalues & \multicolumn{2}{|c|}{$\%$ of Variance } \\
\hline Factor 1 & \multicolumn{2}{|c|}{24.342} & Factor 1 & \multicolumn{2}{|c|}{38.629} \\
\hline Factor 2 & \multicolumn{2}{|c|}{22.945} & Factor 2 & \multicolumn{2}{|c|}{23.510} \\
\hline Factor 3 & \multicolumn{2}{|c|}{10.883} & Factor 3 & \multicolumn{2}{|c|}{13.921} \\
\hline Factor 4 & \multicolumn{2}{|c|}{8.523} & & & \\
\hline $\begin{array}{l}\% \text { of total variance } \\
\text { Extracted }\end{array}$ & & & $\%$ of total variance extracted & \multicolumn{2}{|c|}{76.06} \\
\hline
\end{tabular}

Note: F.L.: Factor loadings. Two items for product ethics that are cross-loading could be deleted from further analysis, namely, "the company appropriately indicates the details of product safety on its product packages" and "the company appropriately compensates for damages caused by defects in the products provided." Two items for place ethics that do not satisfy the criterion $(0.05)$ could be deleted from further analysis, namely, "the company refrains from exercising an unreasonable influence or forcing a sales policy on its distributors (wholesalers /retailers)" and "the company refrains from selecting transaction partners based on personal connections without objective criteria."

The result of Bartlett's test of sphericity was found to be significant $\left(x^{2}=41056.1(d f=657)\right.$, $p<0.0$ ), and the result of Kaiser-Meyer-Olkin measure of sampling adequacy was 0.823 . Therefore, the data were suitable for analysis. Exploratory factor analysis of all of our scale items revealed four factors explaining $66.69 \%$ of the variance in this study's constructs, with the first factor explaining $24.34 \%$ and the last factor explaining $8.52 \%$ of the total variance for independent variables. EFA of our scale items revealed four factors explaining $76.06 \%$ of the variance in this study's constructs, with the first factor explaining $38.6 \%$ and the last factor explaining $13.9 \%$ of the total variance for dependent variables. As seen in Table 4, EFA revealed seven factors with eigenvalues greater than 1.00. This 
analysis suggested that the data sample used in this study was unlikely to have been contaminated by common method bias $[99,101]$.

\subsection{Tests of Hypotheses}

SEM was used to verify the hypotheses associated with the proposed model. The goodness of fit of the model hypotheses yielded $\chi^{2}=1768.4(d f=657), \mathrm{CFI}=0.937, \mathrm{NFI}=0.907, \mathrm{NNFI}=0.935, \mathrm{GFI}=$ 0.862 , AGFI $=0.837$, and RMSEA $=0.058$; therefore, the model's goodness of fit satisfies the criteria.

To test the causal relationships between the constructs, the hypothesized causal paths were estimated. Ten hypotheses were supported, and one was not supported. The results are shown in Figure 2 and Table 5. For H1-1, H1-2, H1-3, and H1-4, the results indicate that the specified areas of ethical marketing practices are closely related to the consumer-brand relationship. The proposed path for product-related ethics was significant and a standardized path coefficient for consumer-brand relationship quality was $\gamma=0.237$ ( $p<0.001$ for H1-1). Thus, hypothesis H1-1 was supported. The proposed path for price-related ethics was significant and a standardized path coefficient for consumer-brand relationship quality was $\gamma=0.158$ ( $p<0.001$ for H1-2). Thus, hypothesis H1-2 was supported. The proposed path for place-related ethics was significant and a standardized path coefficient for consumer-brand relationship quality was $\gamma=0.079(p<0.05$ for H1-3). Thus, hypothesis H1-3 was supported. The proposed path for promotion-related ethics was significant and a standardized path coefficient for consumer-brand relationship quality was $\gamma=0.468(p<0.001$ for H1-4). Thus, hypothesis H1-4 was supported.

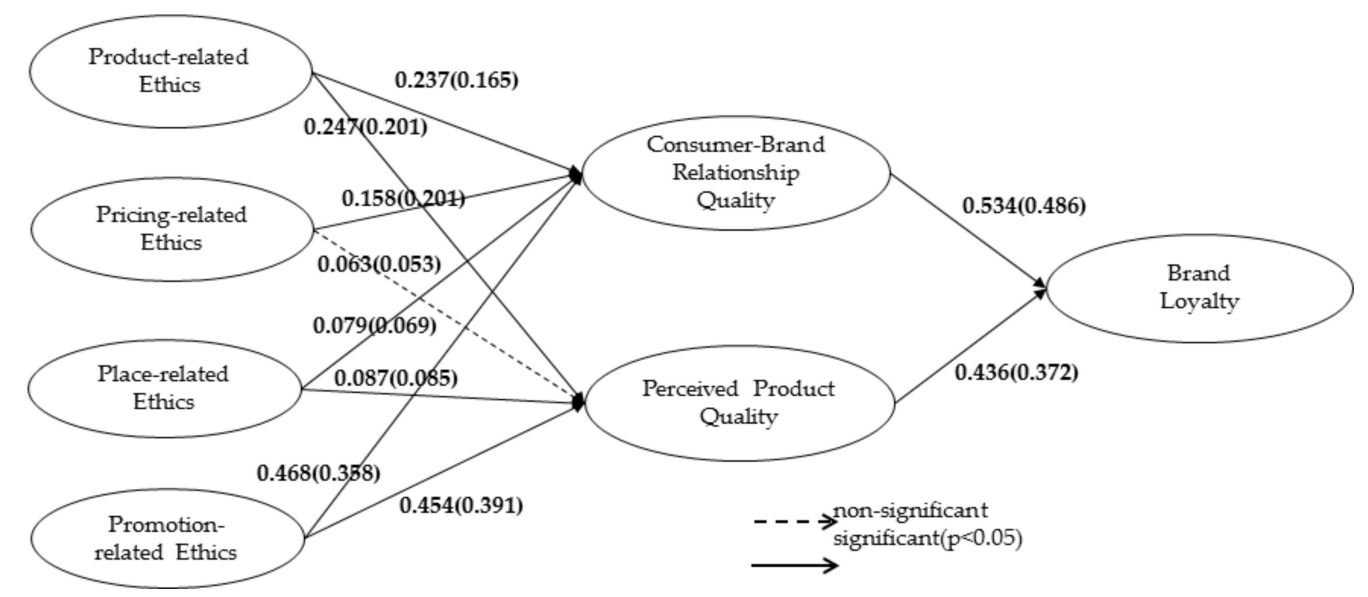

Figure 2. Results of path analysis.

Table 5. Summary of the hypothesis tests.

\begin{tabular}{llll}
\hline Hypothesis & S.E & Standardized Coefficients & Supported \\
\hline H1-1: Product -> CBRQ & 0.056 & $0.237^{* * *}(0.165) / \mathrm{z}=8.86$ & Yes \\
H1-2: Price -> CBRQ & 0.075 & $0.158^{* * *}(0.201) / \mathrm{z}=7.29$ & Yes \\
H1-3: Place -> CBRQ & 0.097 & $0.079^{* *}(0.069) / \mathrm{z}=1.998$ & Yes \\
H1-4: Promotion -> CBRQ & 0.053 & $0.468^{* * *}(0.358) / \mathrm{z}=12.97$ & Yes \\
H2-1: Product -> PPQ & 0.035 & $0.247^{* * *}(0.201) / \mathrm{z}=9.77$ & Yes \\
H2-2: Price -> PPQ & 0.057 & $0.063(0.053) / \mathrm{z}=1.44^{\mathrm{n}, \mathrm{s}}$ & No \\
H2-3: Palace -> PPQ & 0.076 & $0.087^{* *}(0.085) / \mathrm{z}=3.22$ & Yes \\
H2-4: Promotion -> PPQ & 0.067 & $0.454^{* * *}(0.391) / \mathrm{z}=12.88$ & Yes \\
H3: CBRQ -> BL & 0.097 & $0.534^{* * *}(0.486) / \mathrm{z}=16.37$ & Yes \\
H4: PPQ -> BL & 0.076 & $0.436^{* * *}(0.372) / \mathrm{z}=19.54$ & Yes \\
\hline
\end{tabular}

Notes: n.s. (non-significant); ${ }^{* * *} p<0.001 ;{ }^{* *} p<-0.05 ;^{\mathrm{b}}$ (Unstandardized) Coefficient; CBRQ: Consumer-Brand Relationship Quality; PPQ: Perceived-Product Quality; and BL: Brand Loyalty.

For $\mathrm{H} 2-1, \mathrm{H} 2-3$, and $\mathrm{H} 2-4$, the results indicate that three marketing mix strategies from ethical issues are closely related to the consumer-brand relationship, whereas price-related ethics was not. 
The proposed path for product-related ethics was significant and a standardized path coefficient for perceived product quality was $\gamma=0.247$ ( $p<0.001$ for H2-1). Thus, hypothesis H2- 1 was supported. The proposed path for place-related ethics was significant and a standardized path coefficient for perceived product quality was $\gamma=0.087$ ( $p<0.05$ for H2-3). Thus, hypothesis H2-3 was supported. The proposed path for promotion-related ethics was significant and a standardized path coefficient for perceived product quality was $\gamma=0.454$ ( $p<0.001$ for $\mathrm{H} 2-4$ ). Thus, hypothesis $\mathrm{H} 2-4$ was supported. However, the proposed path for price-related ethics was not significant and a standardized path coefficient for perceived product quality was $\gamma=0.063(\mathrm{z}=1.44, p>0.05$ for H2-2). Thus, hypothesis H2-2 was not supported.

To test the mediating effects of consumer-brand relationship quality (H5) and perceived product quality (H6), we conducted Sobel tests to determine whether the indirect effects are statistically significant. For $\mathrm{H} 5$ and $\mathrm{H} 6$, the results indicate that three marketing mix strategies from ethical issues affected brand loyalty through the mediating effects of perceived product quality.

Using the version of the Sobel test, we checked the significance of the indirect influence that explanatory variables have on the dependent variable through the mediating variables. A mediating effect is statistically significant when the z-value is greater than 1.96 or less than -1.96 . The results of the Sobel test are presented in Table 6. For H5, all ethical marketing practices-product-related ethics ( $\mathrm{z}$ $=5.409, p<0.001)$, pricing-related ethics $(z=3.835, p<0.001)$, place-related ethics $(z=1.997, p<0.05)$, and promotion-related ethics $(\mathrm{z}=8.438, p<0.001)$-affected brand loyalty through the mediating effects of consumer-brand relationship quality. For $\mathrm{H} 6$, all ethical marketing practices-product-related ethics $(z=6.011, p<0.001)$, pricing-related ethics $(z=1.778, p=0.075)$, place-related ethics $(z=2.429$, $p<0.001)$, and promotion-related ethics $(\mathrm{z}=8.594, p<0.001)$-affected brand loyalty through the mediating effects of perceived product quality. Thus, hypotheses H5 and H6 were supported.

Table 6. Sobel tests for the mediating effects of consumer-brand relationship quality (CBR) and perceived product quality (PPQ).

\begin{tabular}{|c|c|c|c|c|c|c|c|}
\hline & Path & B & Path & B & Path & B & $\mathbf{z}$ \\
\hline \multirow{4}{*}{ CBR } & Product->CBRQ & 0.237 & & 0247 & \multirow{4}{*}{ CBRQ->BL } & \multirow{4}{*}{0.534} & $5.409^{* * *}$ \\
\hline & Price->CBRQ & 0.158 & Product->BL & 0.247 & & & $3.835^{* * *}$ \\
\hline & Place->CBRQ & 0.079 & & (2012 & & & $1.997^{* *}$ \\
\hline & Promotion->CBRQ & 0.468 & Price->BL & 0.012 & & & $8.438^{* * *}$ \\
\hline \multirow{4}{*}{ PPQ } & Product- $>$ PPQ & 0.247 & & 0016 & \multirow{4}{*}{ PPQ->BL } & \multirow{4}{*}{0.436} & $6.011^{* * *}$ \\
\hline & Price->PPQ & 0.063 & Place->BL & 0.016 & & & $1.778(0.075)$ * \\
\hline & Place->PPQ & 0.087 & & & & & $2.429 * * *$ \\
\hline & Promotion->PPQ & 0.454 & Promotion->BL & 0.348 & & & $8.594^{* * *}$ \\
\hline
\end{tabular}

${ }^{*} p<0.08$ (marginally significant); ${ }^{* *} p<0.05 ;{ }^{* * *} p<0.001 ;$ CBRQ: Consumer-brand relationship quality; PPQ: Perceived product quality; and BL: Brand loyalty.

\subsection{Additional Analysis of the Moderating Effect of Brand Loyalty}

The suggested conceptual model was estimated separately for each of the two groups (e.g., high and low loyalty with brand). The values of selected fit indexes for multi-sample analysis of the path model with equality-constrained direct effects are reported in Table 7, which shows the standardized solutions $[93,95,97]$. The tests show that interaction between product-related ethics, pricing-related ethics, place-related ethics, promotion-related ethics, and consumer-brand relationship quality $\left(\Delta \chi^{2}=0.387, p=0.865\right.$ for product, $\Delta \chi^{2}=12.27, p<0.05$ for price, $\Delta \chi^{2}=15.15, p<0.05$ for place, and $\Delta \chi^{2}=21.28, p<0.05$ for promotion) and perceived product quality $\left(\Delta \chi^{2}=0.392, p=0.873\right.$ for product, $\Delta \chi^{2}=14.21, p<0.05$ for price, $\Delta \chi^{2}=0.675, p=0.831$ for place, and $\Delta \chi^{2}=17.07, p<0.05$ for promotion) were significant. It was hypothesized that the effects of ethical marketing practices on the consumer-brand relationship and perceived product quality would be stronger in consumers with high brand loyalty than that in those with low brand loyalty. 
Table 7. Results of multi-group analysis.

\begin{tabular}{|c|c|c|c|c|}
\hline \multirow{2}{*}{ Path } & \multicolumn{3}{|c|}{ Path Coefficients } & \multirow{2}{*}{ Modification Index $\chi^{2}$} \\
\hline & $t_{1}$ & $t_{2}$ & Difference & \\
\hline Product $\rightarrow$ CBRQ & $0.144(0.095)^{* *}$ & $0.192(0.122)^{* *}$ & -0.048 & $\Delta \chi^{2}=0.387, p=0.865$ \\
\hline Pricing $\rightarrow$ CBRQ & $0.429(0.296) * *$ & $0.228(0.142) * *$ & 0.201 & $\Delta \chi^{2}=12.27, p<0.05$ \\
\hline Place $\rightarrow$ CBRQ & $0.293(0.124) * *$ & $0.052(0.034)^{n . s}$ & 0.241 & $\Delta \chi^{2}=15.15, p<0.05$ \\
\hline Promotion $\rightarrow$ CBRQ & $0.487(0.383) * *$ & $0.165(0.118)^{* *}$ & 0.322 & $\Delta \chi^{2}=21.28, p<0.05$ \\
\hline Product $\rightarrow$ PPQ & $0.125(0.086) * *$ & $0.167(0.089)^{* *}$ & -0.042 & $\Delta \chi^{2}=0.392, p=0.873$ \\
\hline Pricing $\rightarrow$ PPQ & $0.326(0.234) * *$ & $0.099(0.053)^{n s}$ & 0.227 & $\Delta \chi^{2}=14.21, p<0.05$ \\
\hline Place $\rightarrow$ PPQ & $0.077(0.051)^{\text {n.s }}$ & $0.025(0.013)^{\mathrm{ns}}$ & 0.052 & $\Delta \chi^{2}=0.675, p=0.831$ \\
\hline Promotion $\rightarrow$ PPQ & $0.301(0.246)^{* *}$ & $0.031(0.019)^{\mathrm{ns}}$ & 0.270 & $\Delta \chi^{2}=17.07, p<0.05$ \\
\hline $\begin{array}{l}\text { High brand loyalty } \\
\text { Group }\end{array}$ & \multicolumn{4}{|c|}{$\begin{array}{l}\text { Goodness of Fit: } \chi^{2}=3291.4, \mathrm{df}=555, p=0.000, \mathrm{CFI}=0.938, \mathrm{GFI}=0.887, \mathrm{AGFI}= \\
0.880, \mathrm{NFI}=0.881, \mathrm{NNFI}=0.918, \mathrm{SRMR}=0.087, \mathrm{RMSEA}=0.049\end{array}$} \\
\hline Low brand loyalty group & \multicolumn{4}{|c|}{$\begin{array}{l}\text { Goodness of Fit: } \chi^{2}=4019.9, \mathrm{df}=555, p=0.000, \mathrm{CFI}=0.9134, \mathrm{GFI}=0.869, \mathrm{AGFI}= \\
0.860, \mathrm{NFI}=0.864, \mathrm{NNFI}=0.897, \mathrm{SRMR}=0.107, \mathrm{RMSEA}=0.057\end{array}$} \\
\hline
\end{tabular}

Note. CBRQ: Consumer-brand relationship quality; PPQ: Perceived-product quality; and $\mathrm{t}_{1}$ : Sample in high brand loyalty, $\mathrm{t}_{2}$ : Sample in low brand loyalty, and a Standardized, and ${ }^{* *} p<0.05$

\section{Conclusions and Discussion}

We attempted to investigate the components of marketing mix from the standpoint of ethical views and their effect on the consumer-brand relationship and perceived product quality. We also examined whether the consumer-brand relationship quality and consumer-perceived product quality affect corporate brand loyalty.

The results indicate that except price-related ethics, the remaining three marketing mix strategies based on ethical issues are closely related to the consumer-brand relationship. Product-related ethical issues have a positive effect on the consumer-brand relationship quality as well as perceived product quality. Thus, consumers are willing to purchase a product characterized by high level of product safety and quality, well-designed packaging and brand, and eco-friendliness. During product evaluation, consumers' attitudes toward a company are formed in consideration of ethical issues. Product-related ethical issues are crucial when consumers evaluate perceived product quality. The results support the proposed research model statistically and significantly. That is, the corporate marketing mix strategy from ethical issues had an important function in generating a consumer-brand relationship and perceived product quality. The path outcome for product-related ethics and the consumer-brand relationship quality accurately reflects the results found in the extant literature [102,103].

Price-related ethical issues are critical when a consumer is focused on building a strong relationship with a corporation and its brand. This evaluation is often based on whether the company is using predatory pricing strategy, illegal pricing, and fraudulent pricing. An unethical pricing strategy has a negative effect on consumer attitude formation, which includes relationship building with a brand. However, we did not find a correlation between pricing and perceived product quality. Seemingly, consumers are fine with having different perceptions of pricing and product quality. Unethical pricing also does not influence perceived product quality. Pricing-related ethical issues form a set of vital factors that consumers consider when they seek to build a strong relationship with a corporation and its brand by evaluating perceived product quality.

Moreover, place-related ethical issues have a positive effect on the consumer-brand relationship and perceived product quality. Hence, there is a need to improve the relationship with consumers through better place-related ethical issues. One strategy is to strengthen certain areas of ethical marketing practices. For example, in marketing, the role of salespersons is crucial-fostering interpersonal relationships is key. When consumers are provided with products they want, they not only prefer ethical acts through honest distribution channels but also wish to receive products that are customized for their own companies. These desires imply the importance of establishing a sound ethical approach to achieving proper and customized distribution. Some factors such as the degree of sales policy, level 
of partnership, and degree of transparent transaction in place-related ethical issues also considerably influence relationship-building with consumers and product quality evaluation.

Promotion-related ethical issues have a positive effect on the consumer-brand relationship quality and perceived product quality, where the latter two can be reinforced directly only when a company's promotion-related ethics are high. To build a relationship with the consumer, the company should hone authentic communication. When truthful and accurate information about a product, such as its price through advertising, is communicated, the consumer is likely to exhibit high trustworthiness in the corporation and its brand. Factors such as advertising under legal legislation and degree of misleading or deceptive aspects are thus critical when building a strong relationship with the brand; they also improve product quality. Our findings identify factors that should be considered when building a relationship that involves ethical marketing practices, relationship quality, and brand loyalty. The factors of product-, pricing-, and promotion-related ethics-areas of ethical marketing practices - can be used to evaluate the consumer-brand relationship and perceived product quality. If a company improves its relationship quality through improved product-related ethics, we expect a corresponding effect on brand loyalty through brand and emotional relationships with consumers than a direct effect on brand loyalty.

Management- and marketing-related ethics typically involve resolving problems that individuals experience in social life; these problems relate to specific circumstances within corporate management. Within the sphere of corporate ethics, ethical marketing practices involve the relationship between moral beliefs and behavior and corporate marketing practices.

\subsection{Theoretical Implications}

The effects of ethical marketing practices on brand loyalty in B2C transactions and the involvement of the consumer-brand relationship and perceived product quality have important implications. Through our study, we make the following contributions to the extant literature as well as present some practical implications. Our study is different from extant studies on the relationship between ethical marketing practices and brand loyalty because the latter have focused primarily on B2C transactions. Most studies on B2C transactions find that product-, pricing-, place-, and promotion-related ethics have positive effects on brand loyalty or quality. However, it is necessary to induce brand loyalty primarily through improving and reinforcing pricing- or place-related ethics in B2C transactions. However, our contribution is novel because we use an improved research model to analyze the relationship between ethical marketing practices and the consumer-brand relationship, product quality, and brand loyalty, which is common in B2C transactions. The relationships that form between brands and consumers affect the dynamic interactions between consumers and products, which positively affects the brand experience. We thus assert that consumer experiences could be enriched further when the interaction between a consumer and a product includes increased physical contact time.

\subsection{Managerial Implications}

This study systematically analyzes the mediating effects of the consumer-brand relationship and perceived product quality when investigating factors that affect mutual transactional relationships in B2C transactions. These factors affect brand loyalty significantly. We confirmed a significant correlation between ethical marketing practices, which form the basis of transactions and relationship quality.

The findings confirmed that product ethics affect brand loyalty through the mediating effects of the consumer-brand relationship and perceived product quality. That is, companies should develop an emotional approach to reaching consumers when preparing for the upcoming fourth industrial revolution. Companies that anticipate this new era must improve their product offerings not only through safety improvements, better warranties, and eco-friendliness, but also by reconfiguring the role of salespeople to ensure their success.

Pricing-related ethics should also be approached from a new perspective. When a company provides fair prices, it earns the trust of customers and thus strengthens its relationships. Our results 
concerning the consumer-brand relationship and perceived product quality prove this point. Considering the relationship between pricing-related ethics and brand loyalty, consumers of a brand generally want to be provided with a product at more competitive prices than what the consumers of competitors must pay. If a supplier does not provide price elasticity by using fair pricing-related ethics, negative effects can be expected concerning brand loyalty.

No direct effect of pricing-related ethics on brand loyalty was observed, implying that brand loyalty cannot be expected unless pricing-related ethics are reinforced. Moreover, a significantly meaningful relationship between pricing-related ethics and the consumer-brand relationship was observed. In other words, improving pricing-related ethics also improves the consumer-brand relationship quality. However, we found no significant correlation between pricing-related ethics and perceived product quality, implying that reinforcing pricing-related ethics will have very little influence on the perceived product quality.

We also confirmed that a company's place-related ethics influence brand loyalty through the mediators of the consumer-brand relationship and perceived product quality. However, we found no significant causal relationship between place-related ethics and quality, implying that the consumer-brand relationship and perceived product quality in a company deteriorate when place-related ethics are strengthened. Like pricing-related ethics, place-related ethics were also found to affect brand loyalty directly. That is, the level of brand loyalty increases when the company's place-related ethics are high. Place-related ethics were found to have a significant relationship with both the consumer-brand relationship and perceived product quality. A company's place-related ethics are (in)directly influenced by building brand loyalty through the consumer-brand relationship and perceived product quality. Consumers tend to consider issues such as place-related ethics (e.g., ethical acts through honest distribution channels and customized distribution) when they are evaluating a corporate brand. This finding implies that reinforcing place-related ethics can improve both the consumer-brand relationship and product quality

Promotion-related ethics were found to have a direct influence on brand loyalty. Consumers tend to have positive brand loyalty when promotion-related ethics are strong. Improved promotion-related ethics were found to improve both the consumer-brand relationship and perceived product quality. Promotion-related ethics also affect brand loyalty through the mediating effects of the consumer-brand relationship and perceived product quality. The common belief that $\mathrm{B} 2 \mathrm{C}$ transactions have distinct characteristics was verified in this study. We confirmed that ethical marketing practices (product-, pricing-, place-, and promotion-related ethics) affect brand loyalty through the mediators of the consumer-brand relationship and perceived product quality.

Promotion-related ethics play the most important role in forming strong relationships with consumers in terms of both the consumer-brand relationship and product quality. Questions designed to measure promotion-related ethics are related to trust, such as the company providing false and exaggerated advertisements or false information, trying to facilitate transactions through bribes, and applying oppressive sales pressure. In other words, a relationship with the company can be reinforced in B2C transactions when the company that provides the product is an honest firm that does not abuse its market power. The key takeaway here is that companies can survive in the face of fierce competition only when they establish an ethical culture that prioritizes fair and trust-based transactions aimed at strengthening relationships with companies.

The importance of B2C branding is increasing due to intense competition and the need for differentiation. In light of this, how a buyer perceives a supplier not only affects the supplier's corporate image, but also determines the quality of the transactional relationship. Moreover, several factors of ethical marketing practices were found to have a significant effect on the evaluation and maintenance of mutual relationships. This study's results also provide important implications for suppliers' marketing strategy (e.g., marketing mix strategies). We shed light on how buyers form positive perceptions and images through $\mathrm{B} 2 \mathrm{C}$ transactions to create long-term benefits for companies in a corporate environment in which competition is increasingly intense and standardization of technology 
is difficult to achieve. The findings provide valuable implications to support an effective marketing strategy and ethical marketing practices.

\subsection{Limitations and Suggestion for Future Study}

Despite its theoretical and practical significance, this study has several limitations. First, the distinct characteristics of $\mathrm{B} 2 \mathrm{C}$ transactions were not considered when analyzing the path from marketing ethics to brand loyalty. Additionally, we did not take into account the fact that the outcomes associated with each area of marketing ethics - through the relationship between the mediating variables and dependent variables-vary with business type and other characteristics. Consequently, it is difficult to generalize the results of this study. Future studies should conduct more specific analyses.

Future research should consider the following aspects as well: Ethical marketing practices pertain to both individual factors-such as nations/governments, culture, religion, gender, education, employment, and individuality-and circumstantial factors-such as reference groups, compensation-and-reward systems, codes of conduct, types of moral conflicts, organizational influence, and industrial and corporate competitiveness [64]. Compared with other corporate functions, marketing is more visible to the public because marketing forms direct connections between corporate organizations and customers. Similarly, the probability of a moral conflict in a company's relationship with its customers is also higher than in other corporate activities.

One of the reviewers suggested that the ethics questions seem rather challenging to rate on the Likert scale. This issue will be assessed in a future study that controls for social desirability bias while considering ethics, morals, and misbehaviors. An additional limitation is the difficulty of providing sufficient theoretical grounds for the proposed hypotheses, because few studies have examined the relationship between ethical marketing practices and brand and product quality. This limitation made it difficult to measure the consumer-brand relationships and perceived quality of products such as raw materials. Studies on ethical aspects of marketing mix should be conducted in different context or areas. Furthermore, the measurement tools used in this work should be verified in future studies.

Author Contributions: C.-H.J. wrote the paper and worked with J.-Y.L. to conceive and design the experiments J.-Y.L. and C.-H.J. performed the experiments and analyzed the data; C.-H.J. and J.-Y.L. contributed to parts of the experiments and the conclusions.

Funding: This research received no external funding.

Acknowledgments: Thanks to the reviewers for their insightful comments in improving this paper and further highlighting the importance of this avenue of research.

Conflicts of Interest: The authors declare no conflict of interest.

\section{Appendix A}

Table A1. Statistics of the Construct Items.

\begin{tabular}{cl}
\hline \multicolumn{1}{c}{ Construct } & \multicolumn{1}{c}{ Survey Measures } \\
\hline & The details of product safety are appropriately indicated on product packages. \\
& This manufacturer appropriately compensates for damages caused by defective \\
products provided. & This manufacturer refrains from imitating inventions or trademarks of other \\
Product-related Ethics $[1,31,33,64,69,72]$. & companies without permission. \\
& This manufacturer refrains from producing or selling products that cause \\
& environmental pollution. \\
& This manufacturer refrains from intentionally shortening the shelf life of products. \\
& This manufacturer refrains from producing or selling untested products that lead \\
& to social hazards. \\
& This manufacturer offers free exchange, repair, compensation, or refund when \\
defects are found in products.
\end{tabular}


Table A1. Cont.

\begin{tabular}{|c|c|}
\hline Construct & Survey Measures \\
\hline Price-related Ethics $[1,31,33,64,69,72]$. & $\begin{array}{l}\text { This manufacturer refrains from using a predatory pricing strategy of } \\
\text { intentionally lowering prices to eliminate competition. } \\
\text { This manufacturer refrains from engaging in price collusion with competitors. } \\
\text { This manufacturer refrains from attracting customers using low prices and sells } \\
\text { products at high prices. } \\
\text { This manufacturer refrains from differentiating the prices of products of equal } \\
\text { quality. } \\
\text { This manufacturer refrains from increasing prices by engaging in price collusion } \\
\text { with middle merchants (wholesalers/retailers). } \\
\text { This manufacturer refrains from offering drastic price discounts after falsely } \\
\text { pricing products excessively highly. } \\
\text { This manufacturer provides the factors of price increases to consumers and } \\
\text { refrains from increasing prices at its sole discretion. }\end{array}$ \\
\hline Place-related Ethics $[1,31,33,64,69,72]$. & $\begin{array}{l}\text { This manufacturer refrains from exercising unreasonable influence or forcing } \\
\text { sales policy on distributors (wholesalers/retailers). } \\
\text { This manufacturer refrains from selecting transaction partners based on personal } \\
\text { connections without objective criteria. } \\
\text { This manufacturer refrains from unjustly interfering in the activities of } \\
\text { competitors to increase sales. } \\
\text { This manufacturer refrains from falsely advertising low-quality products as } \\
\text { popular products. } \\
\text { This manufacturer refrains from forcing partners to purchase massive quantities } \\
\text { of products. } \\
\text { This manufacturer refrains from controlling transactions by abusing its status. } \\
\text { This manufacturer refrains from engaging in discriminatory transaction practices } \\
\text { by abusing its market dominance. } \\
\text { This manufacturer refrains from falsely informing consumers about the } \\
\text { explanation, indication, expression, and direction of products. }\end{array}$ \\
\hline
\end{tabular}

This manufacturer refrains from providing fraudulent and exaggerated advertisements.

This manufacturer refrains from advertising its products as having higher quality and lower price than its competitors' products without providing objective proof.

Promotion-related Ethics [1,31,33,64,69,72].

This manufacturer ensures that its salespersons do not accept gifts or bribes from customers.

This manufacturer refrains from engaging in coercive sales activities using sales and gift promotions.

This manufacturer keeps all its promises made to the company.

This manufacturer refrains from providing subjective opinions, bluffing, or making vague statements not based on facts to the company.

I really like to talk about the company's brand I like with others

I intend to do more business with the company's brand

I think that this company will deal with the feedback from customers.

I know the differences among product attributes (such as function, appearance,

capability) between this brand and other brands.

Communication with this brand's customers makes me feel intimate.

I would like to help this brand's clients rather than other brands' clients.

I would like to recommend this company's brand to my friends.

Consumer-Brand Relationship Quality

The image of this brand is appropriate.

If this brand is out of stock, I will go to another store to look for it instead of

buying other brands.

I think highly of the prospect of this company's brand.

I will not regret choosing this company's brand.

Among this company's products, no other brands can replace this brand in my heart.

The image of this brand fits my current lifestyle.

If I buy a produce form this company again, I would like to buy this brand again. I can recognize this brand only through its logo or advertising.

This company's product has high quality.

This company's product has a dedicated design.

This company's product has fine workmanship.

Perceived Product Quality [52,67].

I think this company's product is trustworthy.

Brand Loyalty

I am willing to repurchase this company's product in the near future.

I will likely recommend this company's product to others.

This company's product is valuable to me.

\section{References}

1. Bretcu, A. Marketing ethics and postmodern era. Analele Universitatii 'Eftimie Murgu' Resita Fascicola II Studii Economice 2013, 1, 202-209. 
2. Melewar, T.C.; Nguyen, B. Five areas to advance branding theory and practice. J. Brand Manag. 2017, 21, 758-769. [CrossRef]

3. Martin, K.D.; Johnson, J.L. Ethical beliefs and information asymmetries in supplier relationships. J. Pub. Policy. Mark. 2010, 29, 38-51. [CrossRef]

4. Olins, W. Brand New: The Shape of Brands to Come; Thames \& Hudson: New York, NY, USA, 2014.

5. Schramm, J. Perception on Ethics. HR Mag. 2004, 49, 176.

6. Vickers, M.R. Business ethics and the HR role: Past, present, and future. Hum. Resour. Plan. 2005, $28,26-32$.

7. Brunk, K.H. Un/ethical company and brand perceptions: Conceptualizing and operationalizing consumer meanings. J. Bus. Ethics 2012, 111, 551-565. [CrossRef]

8. Kumar, P.; Sanuri, S.; Mokhtar, M. Ethical marketing practices. Mark. Trz. 2016, 28, $29-45$.

9. Amofa, F.; Rachel, Y.; Petrovici, D.; Fearne, A. Towards a framework for understanding Fairtrade purchase intention in the mainstream environment of supermarkets. J. Bus. Ethics 2016, 136, 181-197.

10. Pelsmacker, P.D. A model for fair trade buying behavior: The role of perceived quantity and quality of information and of product-specific attitudes. J. Bus. Ethics 2007, 75, 361-380. [CrossRef]

11. Murphy, P.E.; Laczniak, G.R.; Wood, G. An ethical basis for relationship marketing: A virtue ethics perspective. Eur. J. Mark. 2007, 41,37-57. [CrossRef]

12. Brunk, K.H. Exploring origins of ethical company / brand perceptions: A consumer perspective of corporate ethics. J. Bus. Ethics 2010, 63, 255-262. [CrossRef]

13. Sherwin, D.S. The ethical roots of the business system. Harv. Bus. Rev. 1983, 61, 183-192.

14. Tsalikis, J.; Fritzsche, D. Business ethics: A literature review with a focus on marketing ethics. J. Bus. Ethics 1989, 8, 695-743. [CrossRef]

15. Shea, G.F. Practical Ethics; AMA Membership Publication Division: New York, NY, USA, 1988.

16. Lund, D.B. An empirical examination of marketing professional's ethical behavior in differing situations. J. Bus. Ethics 2000, 24, 331-342. [CrossRef]

17. Anderson, R.E.; Johnson, D.G.; Gotterbarn, D.; Perrolle, J. Using the new ACM code of ethics in decision making. Commun. ACM 1993, 36, 98-107. [CrossRef]

18. Austin, N.K. Ethics: Personal vs. Professional. Working Woman 1992, 7, 28-32.

19. Donaldson, T.; Werhane, P.H.; Cording, M. Ethical Issues in Business; Pearson Prentice Hall: Upper Saddle River, NJ, USA, 1983.

20. Goolsby, J.R.; Hunt, S.D. Cognitive moral development and marketing. J. Mark. 1982, 56, 55-68.

21. Hur, W.M.; Kim, H.; Woo, J. How CSR leads to corporate brand equity: Mediating mechanisms of corporate brand credibility and reputation. J. Bus. Ethics 2014, 125, 75-86. [CrossRef]

22. Sen, S.; Bhattacharya, C.B.; Korschun, D. The role of corporate social responsibility in strengthening multiple stakeholder relationships: A field experiment. J. Acad. Mark. Sci. 2006, 34, 158-166. [CrossRef]

23. Stanaland, A.J.; Lwin, M.O.; Murphy, P.E. Consumer perceptions of the antecedents and consequences of corporate social responsibility. J. Bus. Ethics 2011, 102, 47-55. [CrossRef]

24. Trudel, R.; Cotte, J. This manufacturePay to Be Good? Mit Sloan Manag. Rev. 2009, 50, 61-68.

25. Dunfee, T.W.; Smith, N.C.; Ross, W.T. Social Contracts and Marketing Ethics. J. Mark. 1999, 63, 14-32. [CrossRef]

26. Gaski, J.F. Does marketing ethics really have anything to say? A critical inventory of the literature. J. Bus. Ethics 1999, 18, 315-334.

27. Abela, A.V.; Murphy, P.E. Marketing with integrity: Ethics and the service dominant logic for marketing. J. Acad. Mark. Sci. 2008, 36, 39-53. [CrossRef]

28. Nill, A.; Schibrowsky, J.A. Research on marketing ethics: A systematic review of the literature. J. Macromark. 2007, 27, 256-273. [CrossRef]

29. Brubaker, S. Ethics and regulation in direct marketing. Direct Mark. Int. J. 2007, 1, 55-58. [CrossRef]

30. Jeurissen, R.; Van de Ven, B. Developments in marketing ethics. Bus. Ethics Q. 2006, 16, 427-439. [CrossRef]

31. Low, W.; Davenport, E. Has the medium (roast) become the message? Int. Mark. Rev. 2005, 22, 494-511. [CrossRef]

32. Ludlum, M.; Johnson, J.B. Ethics and law school marketing practices. South. J. Bus. Ethics 2015, 7, 89-104.

33. Malhotra, N.K.; Miller, G.L. An integrated model for ethical decisions in marketing research. J. Bus. Ethics 1998, 17, 263-280. [CrossRef] 
34. Mogan, F.W. Incorporating a consumer safety perspective into the product development process. In Ethic Marketing; Smith, N.C., Quelch, J.A., Eds.; R.D. Irwin: Homewood, IL, USA, 1993; pp. 350-358.

35. Kehoe, T.J. The comparative statics properties of tax models. Canadian J. Econ. 1985, 18, 314-339. [CrossRef]

36. Silham, B. Marketing Mix- An Area of Unethical Practices? Br. J. Mark. Stud. 2013, 1, $20-28$.

37. Chonko, L.B. Ethical Decision Making in Marketing; Sage Publications: Thousand Oaks, NY, USA, 1995.

38. Ortmeyer, G.K. Ethical Issues in Pricing. In Ethics in Marketing; Smith, N.C., Quelch, J.A., Eds.; Irwin: Homewood, IL, USA, 1983; pp. 389-404.

39. Laczniak, G.R.; Murphy, P.E. Ethical Marketing Decisions: The Higher Road; Allyn \& Bacon: Needham Heights, MA, USA, 1993.

40. Drumwright, M.E. Ethical Issues in Advertising and Sales Promotion. In Ethics in Marketing; Smith, N.C., Quelch, J.A., Eds.; Irwin: Boston, MA, USA, 1993; pp. 607-625.

41. Dunn, M.; Davis, S.M. Creating the Brand-Driven Business: It's the CEO Who Must Lead the Way. In Handbook of Business Strategy; Faulkner \& Gray: New York, NY, USA, 2004; Volume 5, pp. 243-248.

42. Thomson, M.; MacInnis, D.J.; Park, C.W. The ties that bind measuring the strength of consumers' attachments to brands. J. Consum. Psychol. 2005, 15, 77-91. [CrossRef]

43. Fournier, S. Consumers and their brands: Developing relationship theory in consumer research. J. Consum. Res. 1998, 24, 343-373. [CrossRef]

44. Reis, H.T.; Shaver, P. Intimacy as an interpersonal process. In Handbook of Personal Relationships, Theory, Research, and Interventions; Duck, S., Ed.; Wiley: New York, NY, USA, 1988.

45. Morgan, R.M.; Hunt, S. The commitment-trust theory of relationship marketing. J. Mark. 1994, 58, $20-38$. [CrossRef]

46. Papista, E.; Dimitriadis, S. Exploring consumer-brand relationship quality and identification: Qualitative evidence from cosmetics brands. Qual. Mark. Res. Inter. J. 2012, 15, 33-56. [CrossRef]

47. Gundlach, G.T.; Achrol, R.S.; Mentzer, J.T. The structure of commitment in exchange. J. Mark. 1995, 59, 78-92. [CrossRef]

48. Chanavat, N.; Bodet, G. Sport branding strategy and internationalization: A French perception of the 'Big Four' brands. Qual. Market Res. Int. J. 2009, 12, 460-481. [CrossRef]

49. Evard, Y.; Aurier, P. Identification and validation of the components of the person-object relationship. J. Bus. Res. 1996, 37, 127-134. [CrossRef]

50. Park, C.W.; MacInnis, D.J. Introduction to the special issue: Brand relationships, emotions, and the self. J. Assoc. Consum. Res. 2018, 3, 123-129. [CrossRef]

51. Aggarwal, P. The effects of brand relationship norms on consumer attitudes and behavior. J. Consum. Res. 2004, 131, 87-101. [CrossRef]

52. Zeithaml, V.A. Consumer perceptions of price, quality, and value: A means-end model and synthesis of evidence. J. Mark. 1988, 52, 2-22. [CrossRef]

53. Aaker, D.A.; Joachimsthaler, F. Brand Leadership Building Assets in the Information Society; Free Press: New York, NY, USA, 2000.

54. Jin, C.H. The effects of creating shared value (CSV) on the consumer self-brand connection: Perspective of sustainable development. Corp. Soc. Respons. Env. Manag. 2018, 25, 1246-1257. [CrossRef]

55. Jin, C.H.; Lee, J.Y. The Halo Effect of CSR Activity Types of CSR Activity and Negative Information Effects. Sustainability 2019, 11, 2067. [CrossRef]

56. Jin, C.H.; Lee, J.Y.; Yoon, M.S. The influence of brand color identity on brand association and loyalty. J. Prod. Brand Manag. 2019, 28, 50-62. [CrossRef]

57. Jin, C.H. Self-concepts in cyber censorship awareness and privacy risk perceptions: What do cyber asylum-seekers have? Comput. Hum. Behav. 2018, 80, 379-389. [CrossRef]

58. Auh, S.; Johnson, M.D. Compatibility effects in evaluations of satisfaction and loyalty. J. Econ. Psychol. 2005, 26, 35-57. [CrossRef]

59. Tweneboah-Koduah, E.; Farley, D.A. Relationship between Customer Satisfaction and Customer Loyalty in the Retail Banking Sector of Ghana. Inter. J. Bus. Manag. 2015, 11, 249. [CrossRef]

60. Oliver, R.L. Whence Customer Loyalty? J. Mark. 1999, 63, 33-44. [CrossRef]

61. Bennett, R.; Rundle-Thiele, S. A Comparison of Attitudinal Loyalty Measurement Approaches. J. Brand Manag. 2002, 9, 193-209. [CrossRef] 
62. Lin, L.Y. The relationship of consumer personality trait, brand personality and brand loyalty: An empirical study of toys and video games buyers. J. Prod. Brand Manag. 2010, 19, 4-17. [CrossRef]

63. Mandhachitara, R.; Poolthong, Y. A model of customer loyalty and corporate social responsibility. J. Serv. Mark. 2011, 25, 122-133. [CrossRef]

64. Ford, R.C.; Richardson, W.D. Ethical decision making: A review of the empirical literature. J. Bus. Ethics 1994, 13, 205-221. [CrossRef]

65. Hoch, S.J. Product experience is seductive. J. Consum. Res. 2002, 29, 448-454. [CrossRef]

66. Rao, C.P.; Singhapakdi, A. Marketing ethics: A comparison between services and other marketing professionals. J. Ser. Mark. 1997, 11, 309-426. [CrossRef]

67. Blackston, M. Observations: Building brand equity by managing the brand's relationships. J. Adv. Res. 2000, 40, 101-105. [CrossRef]

68. Chonko, L.B.; Hunt, S.D. Ethics and marketing management: An empirical examination. J. Bus Res. 1985, 3, 339-359. [CrossRef]

69. Camenisch, P.F. Marketing ethics: Some dimensions of the challenge. J. Bus. Ethics 1991, 10, $245-248$. [CrossRef]

70. Nantel, J.; Weeks, W.A. Marketing ethics: Is there more to it than the utilitarian approach? Eur. J. Mark. 1996, 30, 9-19. [CrossRef]

71. Nnorom, I.C.; Osibanjo, O. Electronic waste (e-waste): Material flows and management practices in Nigeria. Waste Manag. 2008, 28, 1472-1479. [CrossRef]

72. Aguilar, F.J. Managing Corporate Ethics: Learning from America's Ethical Companies How to Supercharge Business Performance; Oxford University Press: New York, NY, USA, 1994.

73. Whysall, P. Retailing and the Internet: A review of ethical issues. Int. J. Retail. Distrib. Manag. 2000, 28, 481-489. [CrossRef]

74. Wartick, S.L. Measuring Corporate Reputation Definition and Data. Bus. Soc. 2002, 41, 371-392. [CrossRef]

75. Prahalad, C.K.; Ramaswamy, V. The co-creation connection. Strat. Bus. 2002, 27, 50-61.

76. Keller, K.K. Building brand equity through corporate societal marketing. J. Publ. Policy Mark. 2002, $21,78-89$.

77. Batra, R.; Ahuvia, A.; Bagozzi, R.P. Brand Love. J. Mark. 2012, 76, 1-16. [CrossRef]

78. Becerra, E.P.; Badrinarayanan, V. The influence of brand trust and brand identification on brand evangelism. J. Prod. Brand Manag. 2013, 22, 371-383. [CrossRef]

79. Helm, V.S.; Renk, U.; Mishra, A. Exploring the impact of employees' self-concept, brand identification and brand pride on brand citizenship behaviors. Eur. J. Mark. 2016, 50, 58-77. [CrossRef]

80. Park, W.; MacInnis, D.J. What's in and What's out: Questions on the Boundaries of the Attitude Construct. J. Consum. Res. 2006, 33, 16-18. [CrossRef]

81. Davis-Sramek, B.; Droge, C.; Mentzer, J.; Myers, M. Creating commitment and loyalty behavior among retailers: What are the roles of service quality and satisfaction? J. Acad. Mark. Sci. 2009, 37, 40-454. [CrossRef]

82. Falk, T.; Hammerschmidt, M.; Schepers, J. The service quality-satisfaction link revisited: Exploring asymmetries and dynamics. J. Acad. Mark. Sci. 2010, 38, 288-302. [CrossRef]

83. Lenka, U.; Suar, D.; Mohapatra, K.J. Soft and hard aspects of quality management practices influencing service quality and customer satisfaction in manufacturing-oriented services. Glob. Bus. Rev. 2010, 11, 79-101. [CrossRef]

84. Beerli, A.; Martin, J.D.; Quintana, A. A model of customer loyalty in the retail banking market. Eur. J. Mark. 2004, 38, 253-275. [CrossRef]

85. Kennedy, M.S.; Ferrell, L.K.; Leclair, D.T. Consumers' trust of salesperson and manufacturer: An empirical study. J. Bus. Res. 2001, 51,73-86. [CrossRef]

86. Poon, D.T.Y.; Prendergast, G.A. New framework for evaluating sponsorship opportunities. Int. J. Adv. 2006, 25, 471-488. [CrossRef]

87. Pyun, D.Y.; Kwon, H.H.; Lee, C.W. The influences of perceived brand quality and ethnocentrism on consumption patterns of a global sport brand: The case of Korean college students. Int. J. Sports Mark. Spons. 2011, 13, 23-37. [CrossRef]

88. Chaudhuri, A.; Holbrook, M.B. The chain of effects from brand trust and brand affect to brand performance: The role of brand loyalty. J. Mark. 2001, 65, 81-93. [CrossRef]

89. Crosby, L.A.; Evans, K.R.; Cowles, D. Relationship quality in service selling: An interpersonal influence perspective. J. Mark. 1990, 54, 68-81. [CrossRef] 
90. Dick, A.S.; Basu, K. Customer loyalty toward an integrated conceptual framework. J. Acad. Mark. Sci. 1994, 22, 99-113. [CrossRef]

91. Alwi, S.F.S.; Ali, S.M.; Nguyen, B. The Importance of Ethics in Branding: Mediating Effects of Ethical Branding on Company Reputation and Brand Loyalty. Bus. Ethics Quart. 2017, 27, 393-422. [CrossRef]

92. Bentler, P.M. EQS: Structural Equation Program Manual; BMDP Statistical Software: Los Angeles, SC, USA, 1992.

93. Byrne, B.M. Structural Equation Modeling with EQS and EQS/Windows: Basic Concepts, Application, and Programming; Sage Publications, Inc. Chanavat: Thousand Oaks, CA, USA, 1994.

94. Kline, R.B. Principles and Practice of Structural Equation Modeling; Guilford Publications: New York, NY, USA, 1998.

95. Bagozzi, R.P.; Yi, Y. In the evaluation of structural equation models. J. Acad. Mark. Sci. 1988, 16, 74-94. [CrossRef]

96. Fornell, C.; Larker, D. Evaluating structural equation models with unobservable variables and measurement errors. J. Mark. Res. 1981, 18, 39-50. [CrossRef]

97. Hair, J.F.; Anderson, R.E.; Tatham, R.L.; Black, W.C. Multivariate Data Analysis; Prentice-Hall: Englewood Cliffs, NJ, USA, 1988.

98. Nunnally, J.C.; Bernstein, I.H. Psychometric Theory; McGraw-Hill Inc.: New York, NY, USA, 1994.

99. Jin, C.H. The role of users' motivations in generating social capital building and subjective well-being: The case of social network games. Comp. Hum. Behav. 2013, 39, 29-38. [CrossRef]

100. Grisaffe, D.B.; Nguyen, H.P. Antecedents of emotional attachment to brands. J. Bus. Res. 2011, 64, 1052-1059. [CrossRef]

101. Podsakoff, P.M.; MacKenzie, S.B.; Lee, J.Y.; Podsakoff, N.P. Common method biases in behavioral research: A critical review of the literature and recommended remedies. J. Appl. Psychol. 2003, 88, 879-903. [CrossRef] [PubMed]

102. Brunk, K.H.; Blümelhuber, C. One strike and you' re out: Qualitative insights into the formation of consumers' ethical company or brand perceptions. J. Bus. Res. 2011, 64, 134-141. [CrossRef]

103. Pelsmacker, P.; De Janssens, W.; Sterckx, E. Fair-trade beliefs, attitudes and buying behavior of Belgian consumers. Int. J. Nonprofit Vol. Sect. Mark. 2006, 11, 125-138. [CrossRef]

(C) 2019 by the authors. Licensee MDPI, Basel, Switzerland. This article is an open access article distributed under the terms and conditions of the Creative Commons Attribution (CC BY) license (http://creativecommons.org/licenses/by/4.0/). 